\author{
Tatiana Mintálová, Michal Vančura, \\ VÁClav TOUŠEK, MARTIN BlaŽEK \\ Palacky University in Olomouc \\ University of South Bohemia in České Budějovice
}

\title{
Innovative environment of the Zlínský Region
}

\section{INTRODUCTION}

Innovations are presently considered one of the most important factors of the regional development. Their introduction enhances the competitiveness of the region, economic growth and living standard in regions. The objective of the contribution is to assess regional innovative potential of the Zlínský region, to present the results of enquiry aimed at the analysis of conditions and hinterland for the innovative enterprise in the Zlínský region and to identify the demands of entrepreneurial subjects in R\&D. Our effort was to analyse the entrepreneurial environment related with research, development and innovations through a number of basic socio-economic information, strategic approaches of the companies, own scientific, research and innovative activities, cooperation forms and other indices. We were also interested in opinions of enquired companies on the entrepreneurial support in the Zlínský region.

\section{METHOD}

The enquiry was held in cooperation with the Technological innovation centre Zlín (organization founded by $50 \%$ by the Tomáš Bata University in Zlín and by $50 \%$ by the Zlín region). In total, we enquired 73 companies active in the Zlínský region (industrial firms and ICT, which stated research, development and innovation as their activities - CZ NACE specification 73.1. Research and development in natural and technical sciences). In order to reach the maximum opinion objectivity, the interviews were aimed at branches with the highest supposed innovation activity. Therefore companies of ICT, manufacturing of plastics, electrotechnics, machinery, manufacturing of rubber and shoes, which are most represented in the Zlínský region, were contacted in the enquiry. The research had a character 
of controlled interviews with top managers, owners or research and development managers. The interviews were based on a structured questionnaire consisting of 49 questions linked to regional enterprise support and analysis of the innovation potential of the entrepreneurial environment of the Zlínský region.

\section{BASIC CHARACTERISTIC}

The Zlínský region is situated in the east of the Czech Republic and its centre is the industrial city of Zlín. As for branches of the enquired companies, more than one half (51\%) is active in two industrial branches - electrotechnics and manufacturing of plastics. This dominance represents the contemporary branch specialisation of the whole Zlínský region. The specialisation of industry in the region underwent a number of transformations. In the past, Zlín was famous for the manufacturing of shoes linked with the name Bat'a. Also machinery and manufacturing of rubber, which were related to the manufacturing of shoes, had a long term tradition in the region. In the transformation process, the tradition had been gradually abandoned and large companies were split into many smaller firms with specialisation on plastics, which has wide range of use, spills over to a number of other industrial branches and presently is one of the main branches in the region. The second important branch is electrotechnics, which links to the tradition of large companies, particularly in the Vsetín, Rožnov and Uherské Hradiště areas. The manufacturing of rubber also belongs to important branches with large companies, such as Barum Continenta, producing tyres, or Gumárny Zubří.

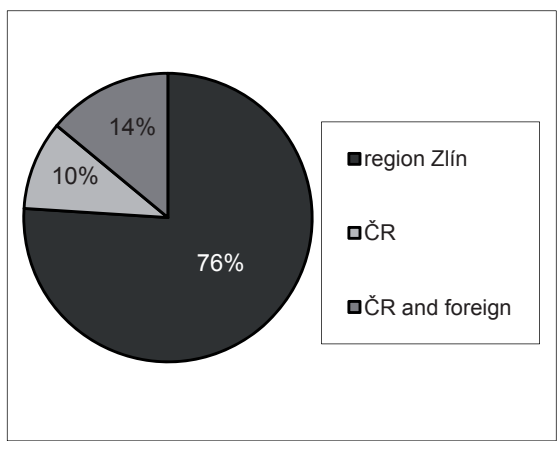

Fig. 1. Company ownership

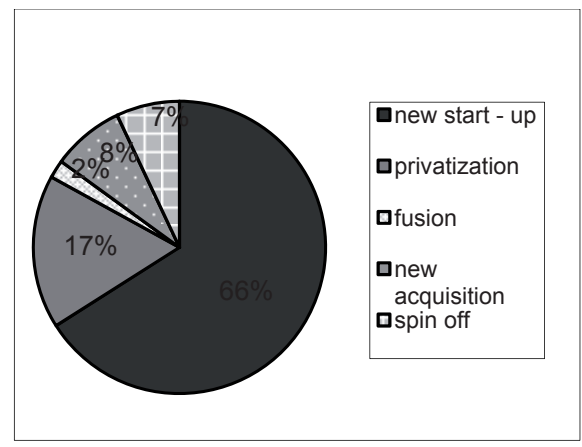

Fig. 2. Company foundation

In ownership structure or enquired companies the domestic capital plays a more important role (in $3 / 4$ of all firms). The method of company foundation is in the category of a new start-up.

\section{RESULTS OF THE INNOVATION ENVIRONMENT ANALYSIS}

Based on the results analysis, we have formed 5 thematic blocks, which appear to be problematic from the point of view of innovative potential and development: 
1. Human resources and education

2. Research, development and innovative activities

3. Cooperation in the field of scientific, research and innovative activities

4. Innovation structure

Rank of these thematic fields correlates with a priority set by entrepreneurial subjects in identifying their weaknesses and threats (we did not take into account generally problematic internal and external factors, which cannot be influenced much).

The enquiry can provide the following conclusions, which are also identified as main barriers of birth and diffusion of innovations in the Zlínský region.

\section{Human resources and education}

The practice assesses particularly the outputs of the educational process - acquired knowledge and skills of students and graduates that should reflect demands of organizations and labour market - not very positively. The entrepreneurial subjects stated dissatisfaction with the quality of education of young people applying for a job: "their language skill is poor, they lack practical skills, methodical preparation, team work, they are dependent:" There is a general feeling of insufficiency in professionals, secondary school and university graduates, in different branches.

The entrepreneurial subjects claim that the motivation of academic workers to cooperate with the practice is none. They criticise conservative thought of $R \& D$ workers taking the research as necessity without practical impact or output, i.e. that the practical use of research is insufficient. The communication between academy and entrepreneurs in the Zlínský region is just developing and the existing experience is not assessed very positively, although it is necessary to take into account the individuality of opinions in relation to positive or negative experience.

\section{Research, development and innovative activities}

The entrepreneurial subjects see the greatest problems in high financial demands of innovations, they criticise the availability of financial resources, as they often face difficulties in a project financing. They experience a lack of resources generally, not only the financial but also material, technical and human resources. They regard as difficult the implementation of new products to the domestic market, to say nothing of the international markets. They claim that the market does not call for innovation itself, it perceives them with suspicion.

From the point of view of the significance of the objectives of R\&D activities it is obvious that the firms endeavour in the first place for the development of new products and through innovations they attempt to enhance productivity and reduce the energetic or material demands. The firms are not interested in expansion or change in the work organization. Following the regulative norms and legislative measures is a common part of their production process.

The most important information source on new technologies are the fairs, conferences, technological exchange, own contact network and professional publications. A number of firms stated that the novelty source for them is to have an eye on their competitors.

The enquired firms dispose of their own R\&D departments, but the project teams are active most in R\&D. They are put together ad hoc for a particular project or research. Three quarters of the enquired firms dispose of their own base for R\&D activities. This is mostly different types of testing and measuring devices and testing laboratories. Apart from their own equipment, the firms use the material base of other companies, schools, research institutes, etc. 
The firms are willing and able to invest into $R \& D$ only minimum percentage of the financial volume of their sales. More than one half (51\%) of the firms spends on R\&D activities less than $5 \%$ of their total sales. Only $15 \%$ of all firms invest into R\&D activities more than one fifth of their sales.

Technological level of the firms is reflected in the necessity to tackle R\&D activities, which help them to keep up with the market and be ahead of their competitors. The realization of R\&D activities is mostly ensured by own resources of the firms. Only $10 \%$ of enquired companies use only external resources, while the size of a firm does not play any role.

According to the answers obtained, we can conclude that $78 \%$ of the enquired companies have two levels of technological advance, i.e. high-tech production based on their own know-how, which is a result of their own R\&D (the highest level of advance) (40\%) and production based on their own, but generally accessible technologies (38\%).

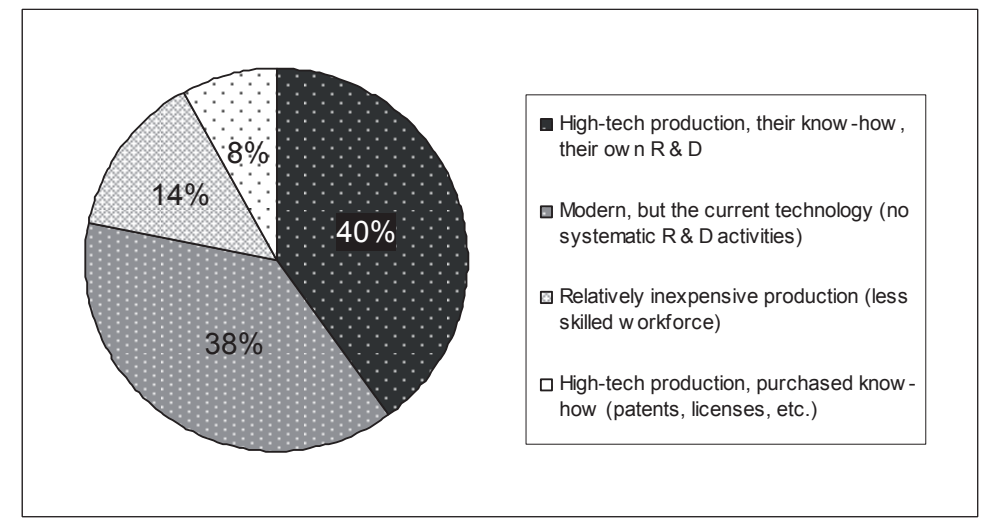

Fig. 3. Resources for realization of R\&D activities

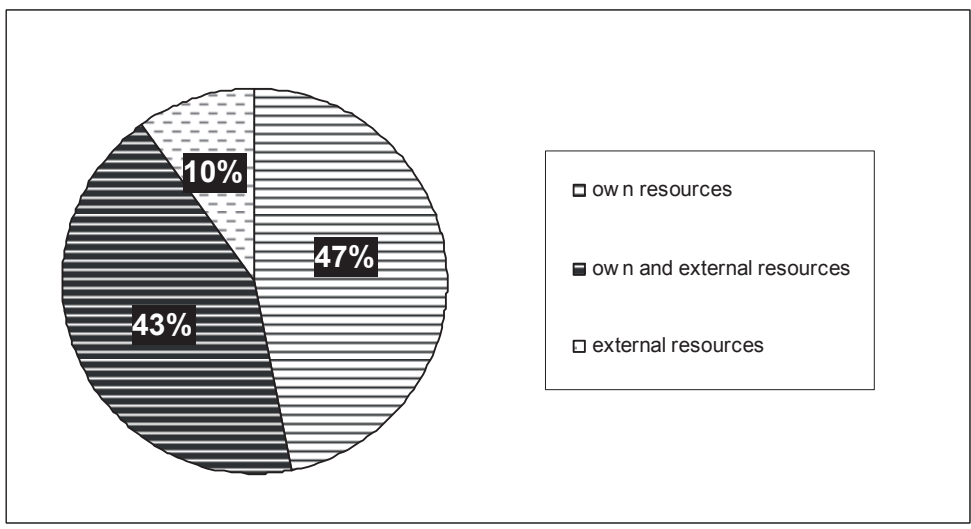

Fig. 4. Technological advance of the firms according to production 
Intellectual property comprises both the results of technical creative activity (inventions and utility models), objects of industrial design, trademark copyright (origin), etc. Some way to protect intellectual property was used by around $56 \%$ of the surveyed businesses.

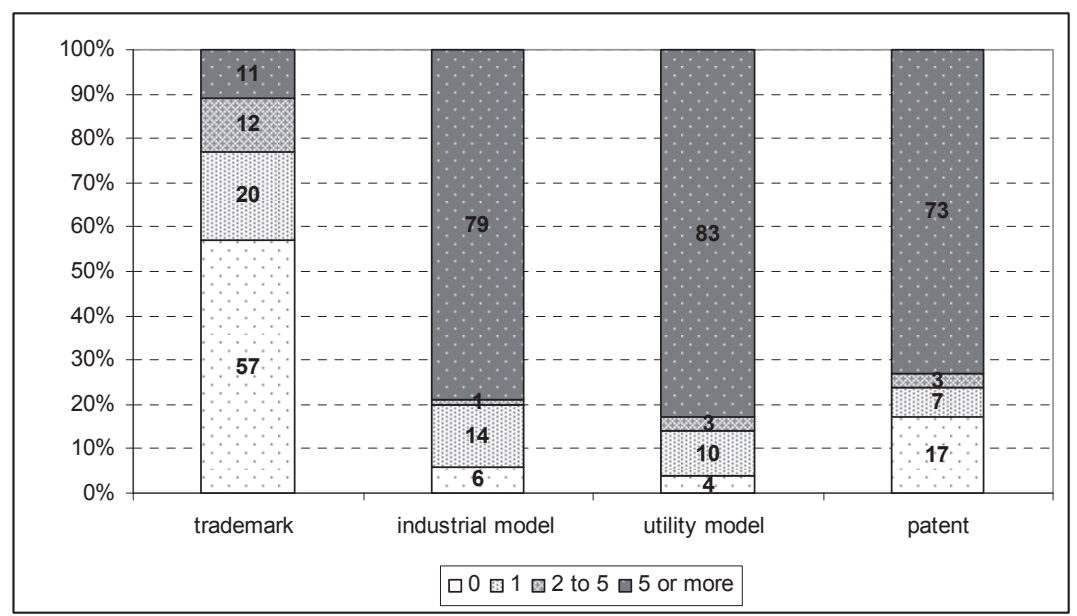

Fig. 5. Way of intellectual property protection

The intellectual property is a very problematic matter and the entrepreneurs were very different in their statements in relation to their positive or negative experience. It is obvious that larger firms exert more effort for the protection of their intellectual property. The decisive factors which discourage them from taking some form of intellectual property protection are finances and distrust towards the quality of protection and demanding administration. For a number of the enquired firms, the patent does not mean a protection but rather a threat to their know-how. Many companies prefer the production. The highest attention, in the case of concrete ways of intellectual property protection, is paid to industrial and utility models, the lowest attention to the trademark.

3 Cooperation in the field of scientific, research and innovative activities

As noted above, the firms generally perceive the cooperation with the universities considerably negatively. The universities mostly realise only the basic research and not the applied one demanded by the practice. The firms stated that they often meet with refusal of the faculties to cooperate in enterprise and solution of commercial problems and needs. On the other hand, the cooperation between universities and companies in the Zlínský region begins to develop. The firms are open for the cooperation with the academic sphere but do not know how to motivate the universities for higher willingness to cooperate. They expect, also in this field, the support of the Zlínský region.

The cooperation with other entrepreneurial subjects is relatively well developed. Around $60 \%$ of firms state the cooperation on research and development activities with another firm or several partners. The cooperation is frequently reciprocal and the bearers of know-how are the placing companies. Generally speaking, smaller firms lack the capital and the cooperation in the field of science; research and innovations has greater importance for them. 
Tab. 1. Portion of entrepreneurial subjects participating in cooperation in R\&D

\begin{tabular}{|l|c|c|c|}
\hline \multicolumn{1}{|c|}{ Number of cooperating institutions } & Universities & $\begin{array}{c}\text { Research } \\
\text { institutes }\end{array}$ & Firms \\
\hline We do not cooperate with an institution & $25 \%$ & $66 \%$ & $40 \%$ \\
\hline We cooperate with 1 institution & $29 \%$ & $19 \%$ & $22 \%$ \\
\hline We cooperate with 2 institutions & $22 \%$ & $14 \%$ & $13 \%$ \\
\hline We cooperate with more than 2 institutions & $24 \%$ & $1 \%$ & $25 \%$ \\
\hline
\end{tabular}

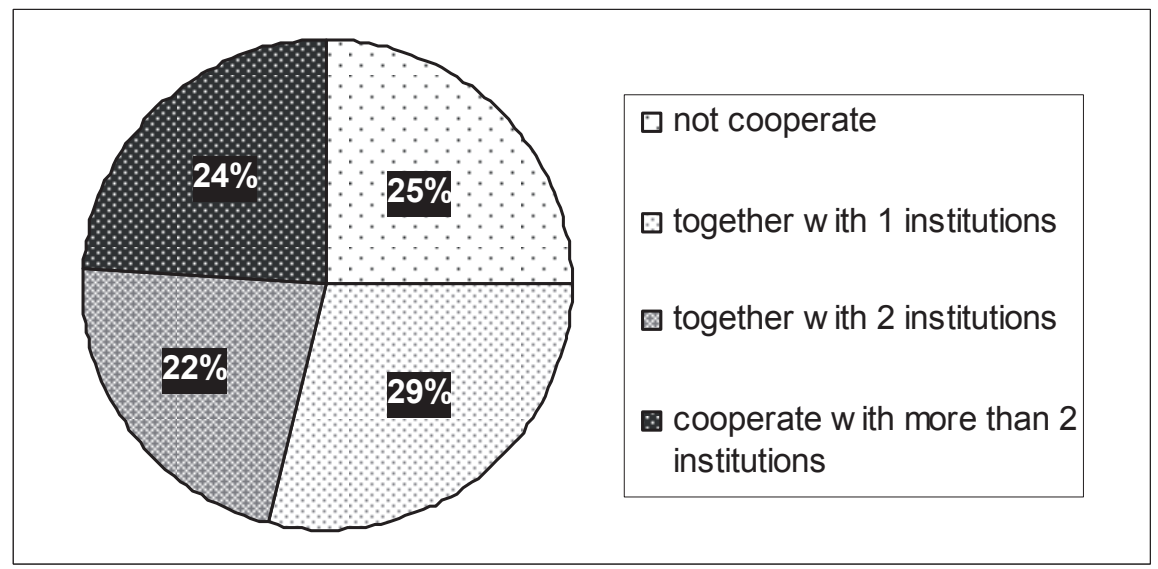

Fig. 6. Cooperation on R \& D activities with other entities

One of the most important forms of cooperation of private and public sector in the Zlínský region is the plastic cluster (PLASTER) which joins the firms dealing with the manufacturing and production of plastics. However, it did not avoid critique for missing information on cooperation opportunities with the cluster (cluster activities). The greatest contribution for the firms is the common purchase of energy and information interchange (common purchase of resources is also planned). The expectations of the firms regarding the cooperation within the cluster were greater than is the reality. The aviation cluster is also forming in the region. As for the question on the interest of the companies to join some cluster, the greatest interest was in the case of the aviation cluster. Almost half of the enquired would accept joining some close cluster. There is also interest in concentration of firms active in ICT.

\section{Innovation structure}

The regional authority was criticised by entrepreneurial subjects several times. The greatest problem is the insufficient communication and activity of the regional authority towards the needs of the entrepreneurial environment. The most firms state that they have no relations to the Zlínský region authority, they do not communicate and they feel no interest from the authority. The activities of the regional authority are not well propagated. The system of existing institutions founded by the regional authority in order to support the enterprise was criticised as well. Despite a wide offer of help in the form of regional authorityfounded institutions for the support of enterprise, it is astounding that the firms do not know these institutions at all, do not know their purpose or the form of support they provide. 


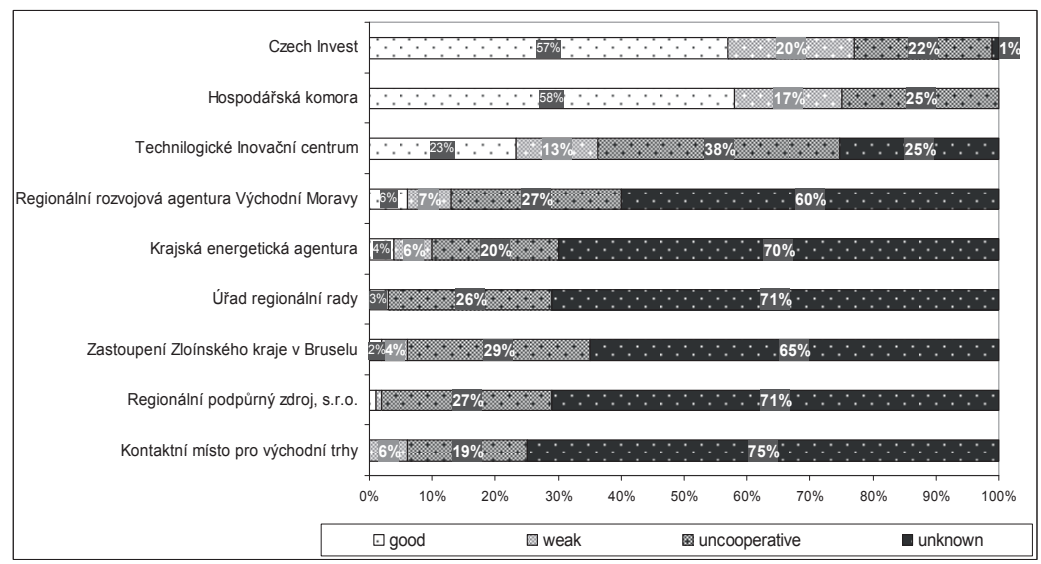

Fig. 7. Business cooperation with institutions established Region of Zlín

The minimal propagation of the institutions founded by the Zlínský region authority was criticised as well.

Generally, two levels of entrepreneurial interests in the support from the regional authority can be defined:

\section{a) level of information and consultation}

- information on topical and prepared subsidy titles, programmes, grants from domestic and international sources, which the firms can acquire and use

- information on tools of entrepreneurial support in the Zlínský region, which are a supportive financial source from the regional budget (micro loans, regional support fund, innovation vouchers),

- international trade and law - legal service for negotiation with domestic but predominantly international companies about potential conditions of signing a treaty or trade, etc.,

- implementation of subsidy support not only to small and middle-sized enterprises, but also to the firms with a higher number of employees, which keep the employment in the region.

\section{b) level of tools of regional enterprise support}

- help with covering the interests from loans to selected perspective companies, e.g. with venture capital (e.g. regional development bank),

- subsidy management - concrete form of help with application creation, in order to gain the subsidy title or project, which has a real chance to succeed.,

- implementation of innovation vouchers.

\section{CONCLUSION}

Based on the analysis of the innovation environment, we can list advantageous and disadvantageous circumstances for the innovation development in the Zlínský region. Those advantageous ones are:

- Relatively extensive investment activity, influence of foreign investments and restructuring of the branches in favour of selected technically demanding branches and services 
represent advantageous indicators for the development of innovative activities and effectiveness of innovation actors.

- There is a potential in interaction between the industry and research, which is influenced by the fact that the industrial branches active in the region kept their industrial research basis.

- Concentration of innovative entrepreneurial subjects in a specific locality also offers advantageous conditions for their joining, forming of the interest coalition (clusters, associations etc.), public presentation of their interests and lobbying.

- Relatively developed networks and competitive environment in the segment of small and middle-sized enterprises.

The set of factors negatively influencing the development of regional innovative infrastructure can be specified as follows:

- Small and middle-sized firms in the region are reflective towards the market factors (product and service quality), however they do not appraise the opportunity and necessity to use other innovation sources (investment sources and networks).

- The innovation incentives are influenced by the market pressure, competitive situation and mobilisation of the human resources of the firms rather than by the cooperative environment, which could enable to form networks among the companies.

- The public support of the firms in their innovation effort is insufficiently assessed and used so far; there is, however, a potential of improving this state.

- The activity of the banking sector towards small and middle-sized enterprises and towards development of regional innovation infrastructure is insufficient.

- The concentration of highly qualified labour force into the segment of micro firms (less than 10 employees, mostly in the ICT) creates the important potential for connection of creativity and enterprise; however, sustainable reproduction of this capital remains a critical question.

The resulting analysis of answers gives a notion of real approach, opinions, demands and proposals of the entrepreneurs of the Zlínský region in the questions regarding the support of enterprise and innovation in the region and regional support as such. The main objective of the enquiry was to acquire the information for defining the measures and system steps, which are necessary in order to create advantageous conditions for innovative enterprise and innovation development in the region. The results of the analytical study should become a base for actualisation of the existing Regional innovation strategy of the Zlínský region.

\section{References}

Frantál, B., Klapka, P., Kunc, J., 2007, Vybrané aspekty inovačního prostředí v regionech ČR. Národohospodářský obzor 7:3, s. 35-45.

Klapka, P., Kunc, J., Jánošík, D., 2007, Inovační potenciál v regionech ČR - komparace krajů. In: Sborník př́íspěvků z X. mezinárodního kolokvia o regionálních vědách. ESF MU a Stredoeurópska vysoká škola, Brno, s. 69-75. (CD ROM)

Klapka, P., Kunc, J., 2007, Možnosti výzkumu inovačního prostředí. Miscelanea Geographica 14, s. $99-104$.

Klapka, P., Kunc, J., 2006, Inovace v prostoru a čase. In: Sborník z IX. Mezinárodního kolokvia o regionálních vědách. ESF MU, Brno, s. 23-29. 
Kunc, J., Klapka, P., Frantál, B., 2008, Innovative potential in the regions of the Czech Republic - economic, societal and regional aspects. In: Svatoňová, H. et al.: Geography in Czechia and Slovakia: theory and practice at the onset of 21st century. Masarykova univerzita, Brno, s. 246-251.

Ptáček, P., 2007, The Regional Institutional Structure of Innovation Policy in the Czech Republic. Pécsi politikai tanulmányok IV., Pécs, p. 53-62, ISBN 978-963-642-148-9.

Ptáček, P., 2006, Inovační politika České republiky. In: Klímová, V. (ed.): IX. Mezinárodní kolokvium o regionálních vědách, ESF MU Brno, s. 31-35. ISBN80-210-4155-2.

Tonev, P., Toušek, V., 2002, Typologie okresů České republiky (podle struktury zaměstnaných s důrazem na odvětví zpracovatelského průmyslu), [The Typology of the Czech Republic Districts (according to the Structure of Employed with the Emphasis on the Branch of the Manufacturing Industry)]. In: M. Balej (ed.): XX. jubilejní sjezd ČSGS. - Sborník tematického okruhu Regionální rozvoj / regionalizace. - Ústí nad Labem: Univerzita J. E. Purkyně, 2002. - s. 67-78. - ISBN 807044-409-6

The article was supported by the grant project of the Czech Science Foundation No. 403/09/0885“ Spatial models of behaviour in changing urban environment: a time geographical approach“"

\section{Innovative environment of the Zlínský Region}

Innovations are presently considered one of the most important factors of the regional development. Their introduction enhances the competitiveness of the region, economic growth and living standard in regions. The objective of the contribution is to assess regional innovative potential of the Zlínský region, to present the results of enquiry aimed at the analysis of conditions and hinterland for the innovative enterprise in the Zlínský region and to identify the demands of entrepreneurial subjects in $R \& D$.

RNDr Tatiana Mintálová

Palacky University in Olomouc, Czech Republic

Department of Geography

Faculty of Science

e-mail: tatiana.mintalova@upol.cz.

Mgr Michal Vančura

University of South Bohemia in České Budějovice, Czech Republic

Department of Geography

Faculty of Education

e-mail: vancura@pf.jcu.cz

Mgr Martin Blažek

University of South Bohemia in České Budějovice, Czech Republic

Department of Geography

Faculty of Education

e-mail:mblazek@pf.jcu.cz

doc. RNDr. Václav TOUŠEK

Palacky University in Olomouc, Czech Republic

Department of Geography

Faculty of Science

e-mail: vaclav.tousek@upol.cz 